\title{
MIĘDZY MARCEM A SIERPNIEM. PRZYKLADY POSTAW OPOZYCYJNYCH MIESZKAŃCÓW BIALOSTOCCZYZNY W KOŃCU LAT SZEŚĆDZIESIĄTYCH I W LATACH SIEDEMDZIESIĄTYCH XX W.
}

DOI: $10.15290 /$ sp.2018.26.07

\begin{abstract}
Abstrakt. Artykuł opisuje przykłady postaw sprzeciwu mieszkańców Białostocczyzny wobec systemu komunistycznego $\mathrm{w}$ latach siedemdziesiątych $\mathrm{XX}$ w., represje stosowane wobec nich i reakcje skonformizowanego otoczenia. Aż do początku lat osiemdziesiątych postawy te były prezentowane przez nonkonformistyczne jednostki, a podłożem protestów grupowych były wyłącznie kwestie ekonomiczne.
\end{abstract}

Słowa kluczowe: opozycja przedsierpniowa, Białostocczyzna, postawy społeczne

Abstract. The article gives the examples of dissident attitudes among the inhabitants of Białystok region against the communist regime in the 1970s, repression used against them as well as the reactions of the conformist surroundings. These attitudes were demonstrated by non-conformist individuals until the beginning of the 1980s, whereas the foundations of group protests were solely economic issues.

Key words: pre-August opposition, Białystok region, social attitudes

Stosunek polskiego społeczeństwa do systemu komunistycznego jest przedmiotem dyskusji historyków co najmniej od momentu jego upadku. Choć początkowo dyskusja ta odbywała się raczej na poziomie publicystycznym, to z czasem postawy społeczne w latach 1944-1989 stały się także przedmiotem analiz naukowych. Zazwyczaj jednak analizy te koncentrowały się na postawach elit, społeczności wielkomiejskich oraz mieszkańców wsi w momentach historycznych przełomów bądź istotnych zmian w polityce władz. Badaniom umykały natomiast postawy społeczne w okresach pomiędzy przełomami, a co za tym idzie długofalowa ewolucja tych postaw ${ }^{1}$. Często polskie

1 W takim ujęciu postawy społeczne badali natomiast socjologowie. Zob. np.: Studenci Warszawy. Studium długofalowych przemian postaw i wartości, red. S. Nowak, Warszawa 1991. 
społeczeństwo stereotypowo przedstawiano jako antykomunistyczny monolit i przeciwstawiano wrogiemu „aparatowi władzy”. Tymczasem należy zgodzić się z wnioskiem sformułowanym przez Hannę Świdę-Ziembę na podstawie własnych badań i obserwacji socjologicznych, rozpoczętych tuż po II wojnie światowej, że linia podziału między „stabilizatorami systemu” i „realizatorami pozasystemowych wartości” biegła „w poprzek formalnego usytuowania ludzi. Po jednej i po drugiej stronie można by znaleźć członków PZPR i bezpartyjnych; szeregowych pracowników różnych instytucji oraz ludzi z aparatu władzy" 2 .

Niniejszy artykuł nie rości sobie pretensji do wyjaśnienia problematyki postaw sprzeciwu mieszkańców Białostocczyzny ${ }^{3}$ wobec komunizmu. Pisałem o tym szeroko $\mathrm{w}$ innym miejscu${ }^{4}$. Jego celem jest raczej wypełnienie luki faktograficznej, ponieważ postawy te $\mathrm{w}$ zasadzie nie były dotąd badane $\mathrm{w}$ odniesieniu do dekady lat siedemdziesiątych XX w. ${ }^{5}$ Historycy-regionaliści skupiali się głównie na badaniu oporu społecznego w okresie tużpowojennym ${ }^{6}, \mathrm{w}$ czasie przymusowej kolektywizacji $\mathrm{wsi}^{7}$ i podczas

2 H. Świda-Ziemba, Człowiek wewnętrznie zniewolony. Problemy psychosocjologiczne minionej formacji, Warszawa 1998, Warszawa 1998, s. 37.

3 Przez określenie to rozumiem obszar geograficzny, jaki obejmowało województwo białostockie w latach 1975-1998.

4 Zob.: Między zaangażowaniem, przystosowaniem i sprzeciwem. Wybory powszechne a postawy mieszkańców województwa białostockiego w latach 1957-1969, mps. rozprawy doktorskiej obronionej w 2017 r. na Wydziale Historyczno-Socjologicznym Uniwersytetu w Białymstoku ( $w$ druku); tam również bibliografia związana $\mathrm{z}$ badaniem postaw społeczeństwa wobec systemu komunistycznego, w tym także postaw oporu i sprzeciwu.

5 O postawach mieszkańców regionu w momentach politycznych przełomów: października 1956 r., marca 1968 r., grudnia 1970 r., czerwca 1976 r. pisał M. Kietliński w niewielkim artykule popularnonaukowym Białystok na zakrętach PRL 1956-1976, „Gryfita” 2000, nr 22, s. 15-19. Najnowszą monografią dotyczącą postaw mieszkańców Polski północno-wschodniej w okresie przełomu 1956 r. i bezpośrednio po nim jest praca M. Markiewicza, Odwilż na prowincji. Białostocczyzna 1956-1960, Białystok-Warszawa 2019. O reakcjach białostoczan na protesty studenckie z marca 1968 r. pisali: D. Boćkowski, Marzec '68 w Białymstoku w świetle materiałów operacyjnych KW MO, „Dzieje Najnowsze” 2008, nr 1, s. 195-202; U. Gierasimiuk, Marzec 1968 r. w województwie białostockim w świetle materiałów aparatu bezpieczeństwa, [w:] "Mała stabilizacja” w województwie białostockim 1956-1970, red. M. Markiewicz, Białystok 2012; J. Sadowska, Epilog historii białostockich Żydów - okres powojenny, [w:] Kres świata białostockich Żydów, red. D. Boćkowski et al., Białystok [b.r.w.], s. 86-90. Monografię opisującą reakcje społeczne mieszkańców regionu na podwyżki cen z czerwca 1976 r. opublikowali: J. Schabieński, K. Sychowicz, Wydarzenia roku 1976 w Polsce pótnocno-wschodniej, Suwałki 2010.

6 Zob.: T. Danilecki, Stan badań nad powojennymi dziejami podziemia niepodległościowego w województwie białostockim, [w:] Podziemie niepodległościowe w województwie białostockim w latach 1944-1956, red. T. Danilecki, Warszawa 2004, s. 13-27. Tam też wykaz literatury przedmiotu. 
stanu wojennego ${ }^{8}$, sporadycznie tylko analizując postawy mieszkańców regionu $\mathrm{w}$ pozostałych okresach ${ }^{9}$. Wprawdzie kilkanaście lat temu $\mathrm{w}$ Instytucie Pamięci Narodowej realizowany był ogólnopolski program badawczy zatytułowany roboczo Opozycja przedsierpniowa w Polsce w latach 1975-1980, jednak jego rezultaty nie zostały nigdy opublikowane ${ }^{10}$. Niniejszy artykuł opiera się częściowo na zebranym wówczas materiale, jednak dotyczy wyłącznie Białostocczyzny. Natomiast jego zakres chronologiczny został obecnie rozszerzony o lata 1968-1974, a co za tym idzie - także uzupełniony nowym materiałem źródłowym i bibliograficznym. Rozszerzenie to jest naturalne $\mathrm{w}$ kontekście rodzących się postaw opozycyjnych polskiego społeczeństwa, któremu przestała odpowiadać „mała stabilizacja” epoki Władysława Gomułki. Jak słusznie dowodził Ireneusz Krzemiński, to przemiany postaw, które nastąpiły w Marcu '68 leżały u źródeł masowości ruchu „Solidarności"11.

7 M. Markiewicz, Kolektywizacja wsi w województwie białostockim 1948-1956, Białystok 2010.

8 T. Danilecki, Mieszkańcy Białostocczyzny wobec stanu wojennego, „Rocznik Białostocki” 2018, t. XXI, s. 305-313; T. Danilecki, M. Zwolski, Podlasie i Suwalszczyzna, [w:] Stan wojenny $w$ Polsce 1981-1983, red. A. Dudek, Warszawa 2003, s. 413-475; M. Kietliński, Stan wojenny na Białostocczyźnie 13 grudnia 1981-22 lipca 1983, Białystok 2001; idem, Szkice do dziejów stanu wojennego w województwie białostockim, Białystok 2012.

9 Zob.: K. Sychowicz, NSZZ „Solidarność” Region Białystok, [w:] NSZZ Solidarność 1980-1989, t. 5. Polska środkowo-wschodnia, red. Ł. Kamiński, G. Waligóra, Warszawa 2010, s. 11-107. O postawach sprzeciwu mieszkańców regionu wobec systemu komunistycznego w ostatnich latach jego trwania zob.: T. Danilecki, NSZZ "Solidarność" i opozycja demokratyczna w województwie białostockim u schyłku lat osiemdziesiątych XX w., [w:] Między systemami. Społeczeństwo Polski pótnocno-wschodniej wobec przemian ustrojowych 1989 roku, red. M. Markiewicz, A. Pyżewska, Białystok 2014, s. 52-68; M. Kietliński, Postawy władzy i opozycji w województwie białostockim u schytku lat osiemdziesiatych XX w., [w:] Między systemami..., s. 69-89.

$10 \mathrm{~W}$ ramach tego programu przygotowany został artykuł monograficzny Opozycja przedsierpniowa (1975-1980) w województwach białostockim, łomżyńskim i suwalskim, którego autorami byli M. Zwolski i T. Danilecki. Pierwszy z autorów opisał postawy opozycyjne w województwach suwalskim i łomżyńskim, drugi zaś - w białostockim. Materiał ten znajdował się w bardzo ograniczonym obiegu naukowym. Na maszynopis ten powoływał się K. Sychowicz w artykule: NSZZ "Solidarność" Region..., passim, a także M. Zwolski (NSZZ „Solidarność" Region Pojezierze, [w:] NSZZ Solidarność 1980-1989..., s. 111-159) oraz A. Malczyk i J. Markiewicz we wstępie i przypisach do wyboru źródeł: Województwo białostockie w ocenie SB 1980-1985, Białystok 2011, passim oraz B. Bujwicki w swojej książce wspomnieniowej: Mój rok 1980, Białystok 2013, s. 678.

11 I. Krzemiński, Antysemityzm, socjalizm i "nowa świadomość”. Długofalowe konsekwencje Marca 68, [w:] Marzec 1968. Trzydzieści lat później. Materiały konferencji zorganizowanej pod patronatem Prezydenta m. stot. Warszawy przez Instytut Historyczny UW, Instytut Studiów Politycznych PAN oraz Żydowski Instytut Historyczny przy wspótpracy Wydawnictwa Naukowego PWN SA na Uniwersytecie Warszawskim 6 i 7 marca 1998 r. Tom I. Referaty, red. M. Kula et al., Warszawa 1998, s. 280. 
Do niniejszego opisu wykorzystano dokumenty operacyjne aparatu bezpieczeństwa przechowywane w Oddziałowym Biurze Udostępniania i Archiwizacji Dokumentów OBUiAD IPN w Białymstoku (obecnie Oddziałowe Archiwum) i Biurze Udostępniania i Archiwizacji Dokumentów BUiAD IPN w Warszawie (obecnie Archiwum IPN), dokumenty Komitetu Wojewódzkiego PZPR w Białymstoku i Komitetu Zakładowego PZPR w Białostockich Zakładach Przemysłu Bawełnianego „Fasty” przechowywane w Archiwum Państwowym w Białymstoku, archiwalia dotyczące Duszpasterstwa Akademickiego i ruchu oazowego z zasobu Archiwum Archidiecezjalnego w Białymstoku. Wykorzystane $\mathrm{w}$ artykule nieautoryzowane relacje świadków i uczestników zdarzeń były przydatne przy ustalaniu faktów oraz weryfikacji informacji zawartych w dokumentach aparatu władzy.

Przed narodzinami w Polsce ruchu "solidarnościowego" zorganizowane grupy opozycji antysystemowej ${ }^{12}$ praktycznie nie istniały $\mathrm{w}$ miastach liczących poniżej 100 tys. mieszkańców. Jedynie w nielicznych takich ośrodkach funkcjonowały małe grupki lub pojedyncze osoby, związane na ogół z opozycją z najbliższych dużych miast. Ich działalność ograniczała się zazwyczaj do kolportażu prasy i literatury bezdebitowej ${ }^{13}$. Podobna sytuacja panowała w Białostockiem. Po 1956 r. społeczeństwo stopniowo przestawało postrzegać system komunistyczny jako "zewnętrzną, obcą i narzuconą konieczność" i zaczynało traktować go jako „naturalny teren życia” ${ }^{14}$. Działo się tak pomimo (dla jednych) czy z powodu (dla innych) powszechnej świadomości „miękkich” represji, którymi władze groziły każdemu, kto chciałby przekroczyć zakreślony przez nią, co prawda względnie szeroki, margines wolności i scenariusz możliwych zachowań jednostek. Kryteria poparcia bądź odrzucenia systemu, który zaczął być postrzegany jako nieodwracalny, zaczęły się zacierać. Ludzie skupili się na realizacji własnych, życiowych ce-

12 Mam tu na myśli zdefiniowane przez Romana Bäckera pojęcie opozycji politycznej sensu largo istniejącej w systemach totalitarnych, której podstawowym wyróżnikiem jest zdolność do formułowania programów politycznych. Istnieje ona - zdaniem Bäckera - w dwóch formach: „wąskiej, ograniczonej do elit kontestatorów, środowisk dysydenckich i krytycznych grup intelektualistów oraz masowej, obejmującej swoim oddziaływaniem znaczne grupy społeczne". Nie dąży ona do współudziału w sprawowaniu władzy i formułuje swoje postulaty językiem odmiennym od "obowiązującej w danym systemie gnozy politycznej" (idem, Opozycja a totalitaryzm. Problemy klasyfikacyjne, [w:] Opozycja w systemach demokratycznych i niedemokratycznych, red. K. Łabędź, M. Mikołajczyk, Kraków 2001, s. 63).

13 Ł. Kamiński, G. Waligóra, Małe ośrodki ruchu zwiqzkowego i ich rola w latach 1980-1990, [w:] Tam też była "Solidarność". Małe ośrodki ruchu związkowego i ich rola w latach 1980-1990, red. A. Pyżewska, M. Zwolski, Białystok 2012, s. 15.

H. Świda-Ziemba, op. cit., s. 34 . 
lów. Względną akceptację systemu ułatwiała możliwość realizacji „bezpiecznej prywatności z perspektywą polepszania swego losu", pracy pozytywistycznej, dostępu młodzieży do rozrywki, swobody ubioru, względnego nieuczestniczenia w życiu publicznym ${ }^{15}$. W sprawach polityki bieżącej, zwłaszcza wśród młodzieży, widoczna była bierność. Przeważająca większość młodych respondentów OBOP z 1959 r. nie interesowała się polityką w ogóle ${ }^{16}$. Względną trwałość takiego stosunku do rzeczywistości obrazują wyniki międzynarodowych badań OBOP przeprowadzonych w 1967 r., w których prawie połowa polskich respondentów uznawała za najwłaściwszą postawę życiową „bierne przystosowanie się do okoliczności” 17.

Mimo postępującej stabilizacji i większego otwarcia władzy na potrzeby zwykłych ludzi, zachowania mieszkańców Białostocczyzny determinował stale tradycyjny, chłopski konserwatyzm. Wyraźna rozbieżność między głęboko utrwalonymi postawami a zewnętrznymi zachowaniami była tutaj większa niż wśród mieszkańców obszarów rozwijających się szybciej, mających inne doświadczenia historyczne. Do wszelkich nowinek ideologicznych i cywilizacyjnych odnoszono się tutaj nieufnie, akceptując jedynie to, co nie kolidowało zasadniczo z wartościami obowiązującymi dotychczas. Ideologiczne wartości systemu często przyjmowano w sposób czysto instrumentalny.

Nowy podział administracyjny kraju wprowadzony w 1975 r. odzwierciedlał w znacznym stopniu historyczne różnice charakterystyczne dla poszczególnych ziem wchodzących w skład "dużego" województwa utworzonego po wojnie. Jednocześnie zmniejszył znaczenie Białegostoku - dotychczasowego centrum regionu - choć liczba jego mieszkańców dynamicznie rosła, sięgając w końcu dekady (głównie za sprawą migracji ze wsi) 200 tys. ${ }^{18}$ „Wykrojone" z dotychczasowego województwa białostockiego nowe jednostki administracyjne: województwo łomżyńskie i suwalskie były dość podobne rolnicze, słabo zurbanizowane i uprzemysłowione ${ }^{19}$. Białostocka wieś była biedna i przeludniona, co potęgowało tylko wspomaganą przez władze

15 Ibidem, s. 181.

16 J. Sadowska, W poszukiwaniu normalności - młodzież Białostocczyzny czasów „małej stabilizacji” (1956-1970), [w:] „Mała stabilizacja”..., s. 180.

17 T. Konwicka et al., Obraz świata w roku 2000. Raport wstępny na podstawie badania z roku 1967, Warszawa 1969, s. 10 [www.tnsglobal.pl, dostęp: 5 XI 2010].

18 J. Sadowska, Białystok za Gomułki i za Gierka (1956-1980), [w:] Historia Białegostoku, red. A. Cz. Dobroński, Białystok 2012, s. 509.

19 W woj. białostockim w przemyśle pracowało wówczas 61 tys. mieszkańców, suwalskim 29 tys., łomżyńskim - 18 tys. W łomżyńskim zaledwie 35,7 proc. ogółu mieszkańców żyło w miastach, podczas gdy w suwalskim i białostockim odpowiednio 49,9 proc. i 57,7 proc. (Polska w liczbach, Warszawa 1985, s. XVII-XIX). 
„ucieczkę" do większych ośrodków miejskich. Z tego powodu w drugiej połowie lat siedemdziesiątych Białystok stał się miastem, w którym odsetek ludności pochodzenia wiejskiego był najwyższy w Polsce ${ }^{20}$. Funkcjonowało tu kilka zakładów zatrudniających po 3-6 tys. osób. Niewielka liczba mniejszych przedsiębiorstw istniała w pozostałych miastach województwa. Wspólną cechą środowisk miejskich był brak wewnętrznej spoistości, wynikający z ich napływowego charakteru. Szkoły wyższe zlokalizowane w stolicy województwa nie miały tradycji przedwojennych ${ }^{21}$. W końcu lat sześćdziesiątych studiowało $\mathrm{w}$ nich ponad 4,5 tys. osób ${ }^{22}$. Środowisko twórcze miasta liczyło w połowie następnej dekady nie więcej niż czterysta osób (głównie dziennikarzy, pisarzy, muzyków i plastyków) ${ }^{23}$. Istotnym elementem dezintegrującym ponad 600-tysięczną społeczność Białostocczyzny były różnice narodowościowo-religijne dzielące większość polską i liczącą ponad 100 tys. mniejszość białoruską, które przekładały się na ich stosunek do powojennej rzeczywistości ${ }^{24}$. Aż do połowy lat pięćdziesiątych XX w. wielu mieszkańców regionu uczestniczyło $\mathrm{w}$ działaniach antykomunistycznego podziemia niepodległościowego i na długo zapamiętało brutalne represje, zastosowane wobec nich przez władze. Duża część tutejszych Białorusinów przez całe powojnie czynnie opowiadała się za nowym ustrojem, a pozostali akceptowali system w sposób bierny. Po 1956 r. tutejsi Polacy przyjęli postawę przystosowania się do istniejącego porządku. Władze wykorzystywały tę sytuację, utrzymując stałe napięcie pomiędzy obiema grupami ${ }^{25}$.

Na społeczną specyfikę regionu nakładały się także zjawiska typowe dla całego kraju, z których najważniejszym było wchodzenie w dorosłość kolejnych pokoleń urodzonych i wychowanych już po wojnie, w realiach PRL.

20 A. Sadowski, Procesy ruralizacji. Ludność wiejska w mieście, Kraków 1994, s. 16.

21 Akademia Medyczna i Wieczorowa (od 1963 r. Wyższa) Szkoła Inżynierska (przekształcona w 1974 r. w Politechnikę Białostocką) powstały w 1950 r. Filię Uniwersytetu Warszawskiego zorganizowano w $1968 \mathrm{r}$. W połowie lat siedemdziesiątych powstał w mieście Wydział Lalkarski PWST i filia PWSM.

22 Białostockie, red. M. Gnatowski, Warszawa 1969, s. 215.

23 Oddziałowe Biuro Udostępniania i Archiwizacji Dokumentów IPN w Białymstoku (dalej: AIPN Bi), sygn. 045/2162/13, Program działań operacyjnych Wydziału III KW MO w Białymstoku do 1980 r., 23 IX 1975, k. 2. Na początku lat osiemdziesiątych było to ok. 450 osób (A. Walicki, Twórcy i kultura Białegostoku. Refleksje z badań środowiskowych, [w:] Studia nad procesami rozwoju regionu białostockiego w 40-leciu PRL, red. M. Gnatowski et al., Białystok 1985 , s. $145-146$.

24 W 1980 r. województwo zamieszkiwało 641 tys. osób (Rocznik statystyczny województwa białostockiego, Białystok 1986, s. 20).

25 E. Mironowicz, Polityka narodowościowa PRL, Białystok 2000, s. 103. 
Toteż „polskie miesiące” przebiegały w regionie znacznie łagodniej niż w innych częściach kraju i nigdy nie dochodziło tu do większych zaburzeń społecznych. Owszem, w październiku 1956 r. w Białymstoku wiecowano 26, ale już marzec 1968 r. przebiegł bardzo spokojnie ${ }^{27}$. W grudniu $1970 \mathrm{r}$. - z powodów ekonomicznych - krótko strajkowały załogi kilku białostockich zakładów ${ }^{28}$.

Do końca lat siedemdziesiątych nie powstały w regionie żadne zorganizowane grupy o charakterze opozycyjnym. W jednym ze sprawozdań Wydziału III KW MO w Białymstoku z połowy lat siedemdziesiątych stwierdzano jedynie, że nieliczne osoby „,[...] nie włączyły się jeszcze w nurt twórczej pracy, wyczekując na ewentualne pogorszenie się sytuacji w kraju i podejmują lub czekają na możliwość podjęcia destrukcyjnej działalności" ${ }^{29}$. Jedną z takich osób, stanowiących od końca lat sześćdziesiątych obiekt żywego zainteresowania Służby Bezpieczeństwa, była Zofia Lewicka, która po protestach studenckich z marca 1968 r. została relegowana z Uniwersytetu Warszawskiego i wróciła do rodzinnego Białegostoku ${ }^{30}$. Z racji swojej dużej aktywności w ruchu marcowym i nadal żywych kontaktów z jego przywódcami ${ }^{31}$, już od jesieni 1968 r. stała się obiektem intensywnej inwigilacji ze strony aparatu bezpieczeństwa. Władze uniemożliwiły jej kontynuowanie studiów i blokowały wszelkie możliwości znalezienia pracy ${ }^{32}$. Dzięki licznym kontaktom w białostockim światku kulturalnym (stryj Lewickiej Franciszek był dziennikarzem m.in. „Trybuny Ludu”, ogólnopolskiego dziennika wydawanego przez KC PZPR, a ona sama tuż przed podjęciem studiów pracowała krótko w dziale reporterskim "Gazety Białostockiej”), zbudowała szybko wokół siebie niewielkie środowisko osób postrzegających krytycznie gomułkowską rzeczywistość. Wśród jej najbliższych znajomych znaleźli się dziennikarze: Edward Redliński, który po swoim debiucie literackim (Listy z Rabarbaru, 1967), stawał się coraz bardziej popularny w całym kraju, Tadeusz Gicgier, Zbigniew Nasiadko, Stanisław Pogorzelski, a także niezależ-

\footnotetext{
26 M. Markiewicz, Odwilż na prowincji..., s. 65-103.

U. Gierasimiuk, op. cit., s. 157-169.

30 T. Danilecki, Zofia Lewicka-Pezowicz [biogram], www.encysol.pl, [dostęp: 10 XII 2018].

31 Począwszy od 1967 r., kilkakrotnie odwiedzał ją w Białymstoku Józef Dajczgewand (T. Danilecki, Zofia Lewicka - od komandoski do streetworkerki, [w druku]).

32 Pierwsza praca Lewickiej - w Stacji Oceny Sadzeniaków Ziemniaka (1968-1969) w Dojlidach, gdzie zajmowała się m.in. przerzucaniem nawozu - była możliwa tylko dlatego, że miała charakter sezonowy i nie wymagała zgody Urzędu ds. Zatrudnienia (ibidem).
} 
nie myślący działacze białoruscy: literat Sokrat Janowicz ${ }^{33}$, filozof Włodzimierz Pawluczuk i dziennikarz Aleksy Karpiuk. Już w październiku 1968 r. $\mathrm{w}$ mieszkaniu Lewickiej przeprowadzono pierwszą rewizję. Z powodu kilku znalezionych wówczas tekstów autorstwa Redlińskiego właścicielkę zatrzymano na 48 godzin $^{34}$. 17 grudnia 1968 r. Wydział III KW MO w Białymstoku rozpoczął rozpracowanie operacyjne i zastosował wobec niej zakaz opuszczania kraju trwający aż do 1985 r. ${ }^{35}$ Działania SB czasami przybierały charakter manifestacyjny, co miało na celu jej wyizolowanie z otoczenia. Intensywnym rozpracowaniem objęto także osoby z jej najbliższego otoczenia, przede wszystkim Redlińskiego ${ }^{36}$ i Pogorzelskiego, dziennikarza działu rolnego "Gazety Białostockiej" 37. Zainteresowanie SB tym środowiskiem wzrosło nagle po opublikowaniu w 1971 r. w ogólnopolskim tygodniku „Kultura” artykułu Redlińskiego Jakiś, który wstrząsnął lokalnym establishmentem ${ }^{38}$. Po publikacji (będącej prawdopodobnie elementem rozgrywek wewnątrzpartyjnych) funkcjonariusze SB twierdzili, że działalność grupy Redlińskiego i Lewickiej - choć niezorganizowana - miała polegać na: „kompromitowaniu działaczy [partyjnych - dop. aut.], anonimach, inspirowaniu i kolportowaniu różnego rodzaju plotek i paszkwili, docieraniu do czynników centralnych i osób tzw. wysoko postawionych w Warszawie i ich dezinformowaniu o sytuacji w Białymstoku”. "Szczególną nienawiść i wrogość” - zdaniem SB członkowie grupy mieli wykazywać wobec Mieczysława Moczara i organów bezpieczeństwa. „Grupa ta - czytamy w meldunku - reprezentuje typowy rewizjonizm, a ich płaszczyznę ideologiczną stanowi »socjalizm demokratyczny«, bez partii komunistycznej i jej organów wykonawczych, wolna gra

33 Janowicz nieco wcześniej zerwał tajną współpracę z aparatem bezpieczeństwa, która trwała niemal 10 lat (K. Pogorzelski, K. Sychowicz, "TW Kastuś” i Stużba Bezpieczeństwa a środowisko białoruskie na Białostocczyźnie, „Aparat represji w Polsce Ludowej 1944-1989” 2008, nr 1, s. 227-246.

34 AIPN Bi, sygn. 015/775, Notatka informacyjna kierownika Grupy IV Wydziału III KW MO w Białymstoku kpt. W. Pienzina dotycząca E. Redlińskiego, 12 XII 1968, k. 25. Por.: ibidem, Pismo I zastępcy Komendanta Wojewódzkiego MO ds. Służby Bezpieczeństwa woj. białostockiego płk. K. Modelewskiego do W. Mikulskiego, Sekretarza ds. Propagandy KW PZPR w Białymstoku w sprawie rękopisów znalezionych podczas rewizji przeprowadzonej u Z. Lewickiej, 6 XII 1968, k. 30.

35 Wpis na podstawie zapisów kartoteczno-ewidencyjnych (www.katalog.bip.ipn.gov.pl; dostęp: 27 VII 2018).

36 AIPN Bi, sygn. 015/775, Edward Redliński; AIPN Bi, sygn. 015/776 cz. I i II, Akta kontrolno-śledcze w sprawie Edwarda Redlińskiego.

37 AIPN Bi, sygn. 012/1438, Teczka dot. Stanisława Pogorzelskiego.

38 J. Autuchiewicz, "Jakiś" reportaż Edwarda Redlińskiego, „Biuletyn Instytutu Pamięci Narodowej" 2008, nr 8-9, s. 82-85. 
polityczna wszystkich sił w kraju, niczym nieograniczona swoboda życia politycznego, społecznego i ekonomicznego, technokracja nad ideologią i antysowietyzm" ${ }^{39}$. Artykuł Redlińskiego przyspieszył zmiany polityczne w regionie. Ze stanowiska I sekretarza KW PZPR w Białymstoku musiał ustąpić "twardogłowy" Arkadiusz Łaszewicz, sprawujący tę funkcję od listopada 1956 r. Zastąpił go gierkowski „liberał” Zdzisław Kurowski, który próbował zneutralizować opozycyjnie nastawionych literatów i dziennikarzy, dając im możliwości swobodniejszego funkcjonowania w oficjalnym obiegu kultury ${ }^{40}$. Nie oznaczało to jednak zakończenia kontroli SB.

Innym środowiskiem stanowiącym wyłom $\mathrm{w}$ tak pożądanej przez władze jednomyślności społeczeństwa było na początku lat siedemdziesiątych duchowieństwo katolickie. Za szczególnie niebezpieczny władze uważały jego wpływ na młodzież. Tuż po przełomie 1956 r. białostoccy księża rozpoczęli organizowanie Duszpasterstwa Akademickiego (DA). Raporty miejscowej SB dotyczące zachowania duchowieństwa po październiku $1956 \mathrm{r}$. pokazują wzrastającą aktywność duszpasterską księży i nowe formy pracy, zarówno z młodzieżą, jak i dorosłymi ${ }^{41}$. Od 1969 r. eksperymentalny ośrodek Duszpasterstwa Akademickiego prowadził przy białostockiej parafii pw. Chrystusa Króla i św. Rocha ks. Jerzy Gisztarowicz, który osiągał bardzo dobre wyniki w pracy ze studentami, choć równocześnie - jak wynika z materiałów SB - był tajnym współpracownikiem komunistycznej „bezpieki” 42.

39 AIPN Bi, sygn. 015/776, Informacja ppłk. E. Rodziewicza, naczelnika Wydziału III KW MO w Białymstoku do naczelnika Wydziału IV Departamentu III MSW w Warszawie dotycząca przejawów „wrogiej działalności” w środowisku dziennikarskim, 27 II 1971, k. 379.

40 Redlińskiemu pozwolono publikować swoje książki, Włodzimierz Pawluczuk rozpoczął kierowanie Ośrodkiem Badań Naukowych w Białymstoku. Pracę znalazła tam również Lewicka, której pozwolono ukończyć w trybie eksternistycznym studia na Uniwersytecie Łódzkim. Sokrat Janowicz, pracujący od 1971 r. jako pracownik fizyczny w aptece, w 1973 r. otrzymał pół etatu na stanowisku „instruktora ds. organizacji pracy kulturalnej w placówkach terenowych" Miejskiej Poradni Kulturalno-Oświatowej w Białymstoku i mógł publikować swoje opowiadania oraz spotykać się z czytelnikami (T. Danilecki, Dwaj literaci, „Biuletyn IPN” 2005, nr 12, s. 38-39). Zob. też: J. J. Milewski, Województwo białostockie. Zarys dziejów (1919-1975), Białystok 2011, s. 227-229, 233-240.

41 AIPN Bi, sygn. 045/246, Sprawozdanie z pracy referatu ds. bezpieczeństwa publicznego PU ds. BP w Białymstoku za IV kwartał 1957 r. [30 XII 1957], k. 19.

42 Od 1968 r. ks. Gisztarowicz był rozpracowywany przez Wydział IV KW MO w Białymstoku, a 14 sierpnia 1971 r. został pozyskany do tajnej współpracy. Nadano mu pseudonimy: „Przemysław”, „Eryk”, „Kazimierz” i „Sielecki”. Miał być regularnie opłacany i uzyskiwać pomoc m.in. w otrzymaniu paszportu. $Z$ jego usług miał korzystać Wydział IV KW MO w Białymstoku oraz departamenty IV i I MSW. Zob.: Biuro Udostępniania i Archiwizacji Dokumentów IPN w Warszawie (dalej: AIPN), sygn. 02240/24, t. 1, Notatka z przeglądu akt Jerzego Gisztarowicza ps. Kazimierz, 15 V 1987, k. 10 i nast. Por. też: Plany pracy Depar- 
W połowie lat siedemdziesiątych DA działało już przy dwóch białostockich parafiach: p.w. Najświętszej Maryi Panny oraz p.w. Chrystusa Króla i św. Rocha. W skład powstałego wówczas kolegium duszpasterzy akademickich Archidiecezji w Białymstoku wchodzili księża: Jerzy Gisztarowicz, Wacław Lewkowicz, Jan Nieciecki i Stanisław Szczepura. Kolegium przewodniczył lubiany i szanowany ks. Alfred Ignatowicz. Jak wspominał późniejszy aktor Piotr Damulewicz: „[...] tam na tych »tajnych kompletach “ tworzyły się nasze postawy, które stały się naszymi kręgosłupami patriotycznymi, etycznymi, moralnymi" ${ }^{43}$. Ks. Gisztarowicz, dzięki swoim kontaktom z abp. Henrykiem Gulbinowiczem, przewodniczącym Komisji Episkopatu ds. DA, został od jesieni 1976 r. członkiem Podkomisji Życia Wewnętrznego, do której należeli związani z opozycją o. Hubert Czuma, o. Ludwik Wiśniewski i o. Feliks Folejewski. Ks. Gisztarowicz próbował wielokrotnie zapraszać tych duchownych do prowadzenia rekolekcji, jednak stale mieli się wymawiać brakiem czasu, wobec czego w latach 1978-1979 rekolekcje prowadzili m.in. o. Jacek Kłoczowski i ks. Adam Boniecki ${ }^{44}$. Organizował też wykłady dla studentów, prowadzone w latach 1978-1980 m.in. przez byłego oficera Komendy Okręgu Białystok AK-AKO kpt. Władysława Brulińskiego ${ }^{45}$. W latach osiemdziesiątych ks. Gisztarowicz był powszechnie uważany za jednego z najbardziej zaangażowanych duchownych w pomoc opozycji ${ }^{46}$.

tamentu IV MSW na lata 1972-1979, wyb. i opr. M. Biełaszko et al., Warszawa 2007, k. 121, 201, 297; Niezłomni. Nigdy przeciw Bogu, komunistyczna bezpieka wobec biskupów polskich, red. J. Marecki, F. Musiał, Warszawa-Kraków 2007, s. 632. Według informacji SB, będąc duszpasterzem polskim w Bielefeld, miał udzielać informacji na temat swoich spotkań m.in. z Jerzym Giedroyciem i Mirosławem Chojeckim, a także złożyć sprawozdanie z wizyty w Radiu Wolna Europa. Funkcjonariusze SB przypuszczali, że ks. Gisztarowicz ujawnił swoje tajne kontakty kardynałowi Gulbinowiczowi, który udzielił mu na nie zgody, mimo to kontynuowali współpracę z nim. Dwie teczki personalne i trzy teczki pracy ks. Gisztarowicza zostały zniszczone 16 X 1989 r. Zachowały się natomiast materiały Departamentu I MSW z drugiej połowy lat osiemdziesiątych (AIPN, sygn. 02240/24, t. 1-2; Wypis ewidencyjny OBUiAD IPN w Białymstoku dot. Jerzego Gisztarowicza, 17 VIII 2007; Wypis ewidencyjny BUiAD IPN w Warszawie dot. J. Gisztarowicza, 8 V 2008). B. Bujwicki w swoich wspomnieniach przytoczył rozmowę z okresu po 1987 r., w której ks. Gisztarowicz oskarżony przez ks. K. Litwiejkę o współpracę z SB, miał przyznać się do niej (B. Bujwicki, op. cit., s. 678). P. Damulewicz, Duszpasterz z autorytetem, „Goniec Knyszyński” 2004, nr 3, s. 14.

AIPN Bi, sygn. 011/61, Wyciąg z notatki informacyjnej z odbytego spotkania z TW ps. Eryk, 23 III 1978, k. 42. Zob. też: Archiwum Archidiecezjalne w Białymstoku (dalej: AAB), Materiały nieuporządkowane, Wydatki DA przy kościele św. Rocha w Białymstoku w roku akademickim 1978/1979, 1 X 1979. AAB, Materiały nieuporządkowane, Wydatki DA przy kościele św. Rocha w Białymstoku w roku akademickim 1979/1980, 24 X 1980. 
Poza działalnością DA, niepokój SB budził też ruch oazowy rozwijający się na terenie diecezji białostockiej. Szczególne zainteresowanie służb budziła działalność studentki Akademii Medycznej w Białymstoku Marzeny Zagórskiej ${ }^{47}$. W jej białostockim mieszkaniu odbywały się spotkania kilkuosobowej grupy uczestników DA i ruchu oazowego, animowanej przez ks. Stanisława Szczepurę ${ }^{48}$. SB pilnie obserwowała też zachowanie studenta Jacka Smykała, który po głośnym relegowaniu z Pomorskiej Akademii Medycznej w Szczecinie kontynuował studia w AMB, uczestnicząc w spotkaniach DA ${ }^{49}$. Zarówno działalność DA, jak i ruchu oazowego nie miała wprawdzie wielkiego zasięgu ${ }^{50}$, ani stricte opozycyjnego charakteru, jednak sam fakt, że odbywała się poza ramami oficjalnymi powodował, że władze postrzegały ją jako antysystemową.

Zdecydowanie polityczny charakter miały natomiast protesty przeciwko zmianom w konstytucji PRL dokonanym przez władze w lutym 1976 r., wprowadzającym zapisy o przewodniej roli PZPR w państwie, jego socjalistycznym charakterze, nienaruszalności sojuszu z ZSRS. Zapisy te uzależniały także przestrzeganie praw obywatelskich przez władze od wykonywania przez obywateli swoich obowiązków wobec państwa. Wywołały one sprzeciw intelektualistów, wyrażony w tzw. Liście 5951, jednak w regionie nie wzbudziły większych protestów. Pojedyncze osoby, które publicznie je krytykowały, były natychmiast obejmowane rozpracowaniem ze strony SB (np. Henryk Szczerba, który jeszcze w grudniu 1975 r. przesłał do sejmu własny projekt Konstytucji PRL, zaś w styczniu i lutym 1976 r. wysłał do prymasa i sejmu protest przeciwko uchwalonym poprawkom ${ }^{52}$ ).

47 Rozpracowanie prowadzono w ramach sprawy operacyjnego sprawdzenia "Studentka”. Akta nie zachowały się.

48 AIPN Bi, sygn. 011/61, Plan przedsięwzięć operacyjnych do sprawy obiektowej krypt. „Powój”, 27 XII 1977, k. 20v.

49 Ibidem. Jacek Smykał był kontrolowany przez białostocką SB w ramach kwestionariusza ewidencyjnego „Interwencja”. Akta nie zachowały się. Na temat Smykała zob. też: J. J. Lipski, KOR. Komitet Obrony Robotników. Komitet Samoobrony Społecznej, Warszawa 2006, s. 107-108; M. Stefaniak, Sprawa Jacka Smykała jako przykład działalności aparatu represji wobec uczestników Duszpasterstwa Akademickiego o. Huberta Czumy SJ, [w:] Między Warszawa a regionem. Opozycja przedsierpniowa na Pomorzu Zachodnim, red. K. Kowalczyk et al., Szczecin 2008, s. 149-163.

50 W połowie lat siedemdziesiątych liczbę uczniów i studentów aktywnie uczestniczących w działalności DA i ruchu oazowym białostocka SB szacowała na nieco ponad setkę (AIPN Bi, sygn. 045/2162/13, Program działań operacyjnych..., k. 4).

51 A. Friszke, Opozycja polityczna w PRL 1945-1980, Londyn 1994, s. 324-335.

52 W 1964 r. Szczerba został skazany na rok więzienia i grzywnę za to, że w styczniu i marcu 1963 r. wysłał do ministra obrony narodowej i I sekretarza KC PZPR trzy listy „,szkalujące 
Wiosną 1976 r. w regionie żywo dyskutowano na temat zapowiedzianych przez premiera Jaroszewicza podwyżek cen żywności. Przypuszczano, że wyniosą one 100-150 proc., a wprowadzone rekompensaty zostaną cofnięte wraz z pierwszą podwyżką pensji ${ }^{53}$. Pracownicy Filharmonii Białostockiej spodziewali się, że w dużych ośrodkach przemysłowych może dojść do „kolejnego grudnia" 54 . Obawy przed takim scenariuszem były powszechne, a SB przestrzegała PZPR przed możliwymi protestami ${ }^{55}$. Plotkom towarzyszył wzmożony wykup towarów. 21 kwietnia Wydział III KW MO w Białymstoku rozpoczął prowadzenie sprawy operacyjnego sprawdzenia krypt. „Detal", której celem było rozpoznawanie opinii o podwyżkach i neutralizacja napięć 56 .

24 czerwca w Białymstoku spotkało się kierownictwo KW MO. Podobnie jak w całym kraju, funkcjonariuszy oficjalnie zapoznano wówczas z planami podwyżek ${ }^{57}$. Zapewniano o braku powodów do niepokoju, przestrzegając równocześnie przed „nieprzyjemnymi” niespodziankami ${ }^{58}$. Przekonanie milicji o prawdopodobieństwie powtórzenia się "grudniowego" scenariusza obrazują przygotowania do rozwiązania siłowego: ambulatoria zaopatrzono w zapasy leków i innych środków medycznych, zaktualizowano plany obrony komisariatów i posterunków $\mathrm{MO}$, sprawdzono stan zabezpieczenia broni palnej w różnych instytucjach, wprowadzono przyspieszony tryb rozpatrywania spraw karnych i karno-administracyjnych ${ }^{59}$.

Skala ogłoszonych podwyżek wzbudziła powszechne oburzenie ${ }^{60}$. W piątek 25 czerwca pracę przerwało kilka załóg białostockich przedsiębiorstw (w Fabryce Przyrządów i Uchwytów strajkowało 1908 spośród 2913 pracowników, w Zakładzie Wytwórczym Maszyn i Urządzeń Spożywczych „Spomasz" 332 na 456 oraz po kilkadziesiąt osób w „Herbapolu”, Oddziałach Remontowym i Towarowym PKS, Zakładzie Mechanicznym Białostoc-

ustrój społeczny oraz polityczny Polskiej Rzeczpospolitej Ludowej, najwyższe władze państwowe i partyjne" (AIPN Bi, sygn. 015/712/1, Akt oskarżenia przeciwko H. Szczerbie, 30 V 1963, k. 15).

AIPN Bi, sygn. 009/205/2, Informacja TW „Zaremba” nr 72/379/76, 21 V 1976, k. 192.

Ibidem, Informacja TW „Zaremba” nr 74/379/76, 20 VI 1976, k. 196. AIPN Bi, sygn. 012/397, Meldunek z 20 V 1976, k. 20.

57 P. Sasanka, Czerwiec 1976. Geneza, przebieg, konsekwencje, Warszawa 2017, s. 150-151.

58 AIPN Bi, sygn. 047/1839, Protokół z narady służbowej aktywu kierowniczego MO woj. białostockiego, 24 VI 1976, k. 66-67.

59 Ibidem.

60 Na temat protestów robotniczych w regionie w czerwcu 1976 r. więcej zob.: J. Schabieński, K. Sychowicz, op. cit., passim. 
kich Zakładów Ceramiki Budowlanej oraz Zakładzie Aparatury Akustycznej), w kilku zakładach strajk rozpoczął się na II zmianie (Tkalnia Biała BZPB „Fasty”, Huta Szkła, Białostockie Zakłady Graficzne) ${ }^{61}$. Sytuację w Tkalni Białej BZPB „Fasty” opisywał kilka dni później członkom Egzekutywy KZ PZPR jeden z dyspozytorów: „Od godz. 13.20 nie pracowały cewiaczki i snowaczki. Na salę konferencyjną [gdzie odbywały się konsultacje w sprawie podwyżek] wtargnęły pracownice z cewialni i przewijalni. Gdy zszedłem na halę, stały wszystkie zespoły. Na moje pytanie, dlaczego nie pracują, odpowiedź padła: "A bo podwyżki«". Wydanego mistrzom polecenia natychmiastowego powrotu do pracy nie wykonał żaden, a dwaj zaczęli się ostentacyjnie opalać przed halą. Jedna z tkaczek stwierdziła: „32 lata po wojnie i mamy głodować. Należy podnieść o 50 proc. zarobki, bo to hitlerowska okupacja" 62 . Kiedy pracownicy skarżyli się, że z tak niskich zarobków nie można wyżyć, dyrektor Adam Karwowski odpowiedział, że "robotnikom nie potrzeba dywanów i mebli, wystarczy kwaśne mleko i chleb". Kierownik Piotr Miron zapisywał nazwiska pracowników, którzy zabierali głos i to wystarczyło, aby ich zwolnić63.

Charakterystyczną cechą protestów - odnotowaną w raporcie I sekretarza KW PZPR do KC - były próby ich zamanifestowania:

Przerwę $w$ pracy demonstrowano na zewnątrz poprzez wyjście $\mathrm{z}$ budynków zakładowych. [...] $\mathrm{Z}$ reguły pokazywano się $\mathrm{w}$ widocznych miejscach, $\mathrm{np}$. w »Uchwytach « od strony Huty Szkła, zwracano na siebie uwagę okrzykami, rzucaniem różnych przedmiotów. W oddziale remontowym PPKS część załogi (50 [osób? - dop. T. D.]) usadowiła się na wysokiej skarpie, dobrze widocznej niemal w całej dzielnicy przemysłowo-składowej „Bażantarnia”, w pobliżu takich zakładów jak „Herbapol”, Zakład Transportu Przemysłu Mięsnego, PKP, Oddział PKS. Pracownice "Herbapolu” rozsiadły się na płotach, a pracownice Oddziału Przygotowawczego Tkalni Białej w „Fastach” wyszły na holl i przed budynek wydziału ${ }^{64}$.

61 M. Kietliński, Białystok na zakrętach..., s. 18-19; Archiwum Państwowe w Białymstoku (dalej: APB), KM PZPR w Białymstoku, sygn. 113, Informacja dotycząca sytuacji w sprawie zmian w strukturze cen, 29 VI 1976, k. 250; APB, KW PZPR w Białymstoku, sygn. 807, Informacja I sekretarza KW PZPR o przebiegu wydarzeń w zakładach, w których wystąpiły przestoje lub zakłócenia w pracy w dniu 29 VI 1976, k. 139-140. Por.: P. Sasanka, op. cit., s. 257-258.

62 APB, KZ PZPR BZPB Fasty, sygn. 10, Protokół z posiedzenia Egzekutywy KZ PZPR, 29-30 VI 1976, k. 137-138.

63 Relacje zwolnionych tkaczek, opr. tl [Teresa Leszczyńska], „,Biuletyn Informacyjny MKZ NSZZ "Solidarność« Regionu Białystok", nr 30, 24 VI 1981, s. 3.

64 APB, KW PZPR w Białymstoku, sygn. 807, Informacja I sekretarza KW PZPR o przebiegu wydarzeń w zakładach..., k. 139-140. 
Funkcjonariusze Wydziału III KW MO wszczęli osiem spraw operacyjnych, dotyczących każdego ze strajkujących zakładów ${ }^{65}$. Wszystkie protesty zakończyły się po wieczornym odwołaniu podwyżek. W niedzielę 26 czerwca w sześciu największych zakładach województwa białostockiego odbyły się wyreżyserowane „masówki”, podczas których załogi „potępiły” piątkowe "ekscesy". Ale właściwa akcja propagandowa PZPR zaczęła się w poniedziałek. Dziesiątki wieców odbyły się w całym regionie. Na stadion w centrum Białegostoku przy ul. Jurowieckiej spędzono tysiące ludzi. Nad zgromadzonym tłumem widać było transparenty z hasłami: „Demokracja to nie anarchia”, „Warcholstwo nie przejdzie”, „Potępiamy brak poczucia dyscypliny społecznej" ${ }^{\prime 6} .29$ czerwca w białostockich fabrykach zaczęły się wewnętrzne śledztwa egzekutyw POP, mające na celu ustalenie inspiratorów protestów. „Rozmowy indywidualne” miały charakter przesłuchań, po których podejmowano natychmiastowe decyzje kadrowe. W „Fastach”, w wyniku dwudniowych przesłuchań ustalono nazwiska dwunastu mistrzów, którzy „uzewnętrznili swoją niepewną postawę" ${ }^{\prime 7}$. Trudniej śledztwo przebiegało w "Uchwytach”, których załoga była skonsolidowana i miała doświadczenie strajkowe z grudnia $1970 \mathrm{r}$. W sprawozdaniu KW PZPR stwierdzono, że wśród robotników panował "solidaryzm”, polegający na odmowie potępienia strajku oraz podania nazwisk jego organizatorów. $W$ trakcie przesłuchań udało się ustalić inspiratorów strajku z narzędziowni ${ }^{68}$, jednak protestujący z innych wydziałów byli kryci przez kolegów ${ }^{69}$. Nie chcąc wywołać kolejnych niepokojów postanowiono, że represje wobec "prowodyrów” zostaną podjęte dopiero „po wytworzeniu wśród części członków organizacji partyjnej i załogi klimatu dezaprobaty" ${ }^{\prime \prime}$. We wszystkich zakładach opraco-

65 AIPN Bi, sygn. 012/397, Meldunek operacyjny z 17 VII 1976, k. 25v.

66 APB, KW PZPR w Białymstoku, sygn. 807, Informacja I sekretarza KW PZPR o przebiegu wiecu w Białymstoku, 28 VI 1976, k. 159-161.

67 APB, KZ PZPR BZPB Fasty, sygn. 10, Protokół z posiedzenia Egzekutywy..., k. 147. Ostatecznie zwolniono prawdopodobnie pięciu mistrzów: Stanisława Bezubika, Henryka Dziekońskiego, Mieczysława Jabłońskiego, Tadeusza Kirpszę i Romualda Tarasiewicza (Sprawa pięciu mistrzów Tkalni Białej, [opr. MM, ZLP], „Biuletyn Informacyjny MKZ NSZZ »Solidarność« Regionu Białystok", nr 30, 24 VI 1981).

68 Prawdopodobnie chodziło o dwóch pracowników narzędziowni, których nazwiska SB znała już 26 czerwca (AIPN Bi, sygn. 012/397, Meldunek z 26 VI 1976, k. 21).

69 APB, KW PZPR w Białymstoku, sygn. 807, Informacja I sekretarza KW PZPR o przebiegu wydarzeń..., k. 142-143.

70 APB, KW PZPR w Białymstoku, sygn. 808, Informacja I Sekretarza KW PZPR o dalszych przedsięwzięciach organizacyjnych i sytuacji w zakładach na terenie woj, białostockiego, w których w dniu 25 VI 1976 r. miały miejsce przerwy w pracy, 1 VII 1976, k. 1-3. 
wano szczegółowe plany postępowania, mające na celu poprawę dyscypliny, uwzględniające "zarówno wnioski personalne, jak i metody zneutralizowania wpływu elementów warcholskich" ${ }^{\prime 1}$. Kary dyscyplinarne zaczęto wykonywać 2 lipca. Jeden ze zwolnionych z „Fast” mistrzów wspominał:

[...] ok. godziny 12.30 zawiadomiono nas, że mamy się umyć, ubrać i na 12.45 iść do biurowca. Poszliśmy. W małej salce siedziało około 20 osób. Wzywano nas do sąsiedniego pokoju, najpierw pojedynczo, a potem po dwóch. W salce siedział z nami kierownik Miron, pilnował nas. W pokoju, do którego nas wzywali, siedzieli: Karwowski [dyrektor], [Józef] Jagusiak [sekretarz POP], przewodniczący Rady Zakładowej [Jan] Bojanowski, kasjerka, która od razu wypłacała nam pieniądze oraz osoby, których twarze pierwszy raz widzieliśmy. Karwowski wręczył każdemu wymówienie ze słowami: „Od jutra pan nie pracuje, proszę pobrać pieniądze, do widzenia".

Zwolnionym mistrzom zarzucono, że 25 czerwca nie stawili się do pracy ${ }^{72}$. Do połowy listopada zwolniono 58 osób ${ }^{73}$, wymierzono 25 nagan i upomnień, 29 pracowników przeniesiono na gorsze stanowiska, odwołano dwóch zastępców dyrektorów. Przyjęto też rezygnację dyrektora naczelnego Zakładu Mechanicznego $\mathrm{BPCB}^{74}$. Nie zważano na sytuację materialną i rodzinną pracowników. Jedna $\mathrm{z}$ tkaczek była $\mathrm{w}$ ciąży $\mathrm{z}$ trzecim dzieckiem, a jej mąż był inwalidą. Jedyną żywicielkę rodziny zwolniono tylko dlatego, że namawiała innych, aby wstawili się $u$ dyrekcji za koleżanką wyrzuconą tydzień wcześniej75. 51 zwolnionych odwołało się do Terenowej Komisji Odwoławczej ds. Pracy, która w trzech przypadkach nakazała zakładom ponowne ich przyjęcie. 23 osoby, a także pracodawcy trzech przywróconych do pracy odwołali się do Sądu Pracy i Ubezpieczeń Społecznych, który uwzględnił odwołania zakładów, oddalając jednocześnie powództwa zwol-

71 APB, KW PZPR w Białymstoku, sygn. 807, Informacja I sekretarza KW PZPR o przebiegu wydarzeń..., k. 142-143.

72 Sprawa pięciu mistrzów...

73 APB, KW PZPR w Białymstoku, sygn. 808, Informacja Sekretarza KW PZPR do Wydziału Organizacyjnego KC PZPR dotycząca zwolnionych z pracy po 25 VI 1976 r., 12 XI 1976, k. 207-208. W 1981 r. w powołanej przez Wojewodę Białostockiego Komisji ds. ugodowego załatwienia roszczeń pracowników zwolnionych z pracy w $1976 \mathrm{r}$. zarejestrowało się 61 osób (M. Kietliński, Białystok na zakrętach..., s. 19).

74 APB, KW PZPR w Białymstoku, sygn. 808, Informacja Sekretarza KW PZPR o działaniach podjętych w zakładach, w których w dniu 25 VI 1976 r. nastąpiły przerwy w pracy, 5 VIII 1976, k. 81-82. Por.: P. Sasanka, op. cit., s. 295. 
nionych ${ }^{76}$. SB wróciła też do znanej z lat pięćdziesiątych praktyki karania i zastraszania osób prowadzących tzw. propagandę szeptaną wzywając je na rozmowy, inwigilując, przekazując władzom lokalnym informacje o ich „postępkach”, grożąc karami wymierzanymi przez kolegia ${ }^{77}$.

Protesty czerwcowe były największą akcją protestacyjną w województwie przed $1980 \mathrm{r}$. Choć nie miały charakteru politycznego, a jedynie ekonomiczny, to ich cechą charakterystyczną była rodząca się wśród represjonowanych robotników solidarność w postawie sprzeciwu wobec władzy.

Wkrótce po czerwcowych strajkach, za pośrednictwem osób przyjeżdżających z Warszawy, zaczęły docierać do Białegostoku wiadomości o powstaniu Komitetu Obrony Robotników. Stało się tak m.in. dzięki Jackowi Kuroniowi, który tuż po pierwszym procesie robotników z Ursusa (16-17 lipca 1976 r.) rozpoczął odbywanie w Białymstoku służby wojskowej. Stąd za pośrednictwem łączników konsultował z Janem Józefem Lipskim formułę Komitetu ${ }^{78}$. Prawdopodobnie jedną z łączniczek Kuronia była Zofia Lewicka (od początku lat siedemdziesiątych nosząca po mężu nazwisko Lewicka-Pezowicz) ${ }^{79}$. Bywalcy jej mieszkania (stanowiło ono wówczas rodzaj „salonu politycznego") wspominali, że Kuroń pojawiał się tam w mundurze ${ }^{80}$. Gospodyni stale utrzymywała kontakty z dawnym środowiskiem "komandosów", przywożąc do Białegostoku literaturę bezdebitową: Archipelag Gułag, Kronikę wydarzeń bieżacych, wydawnictwa paryskiej „Kultury”, a po powstaniu KOR - „Biuletyn Informacyjny” i „Robotnika” ${ }^{81}$. Środowisko skupione wokół niej było już wówczas świadome prowadzonej przez SB inwigilacji, a co za tym idzie dość hermetyczne. Dlatego prowadzone tam dyskusje raczej nie wykraczały poza wąski krąg ich uczestników. Mimo że oficer SB Zbigniew Zielonka nakazywał działającemu w tym środowisku TW „Waldemarowi” zbieranie

76 Wkrótce otrzymali oni wezwania do Wydziału Zatrudnienia UM w celu podjęcia pracy $\mathrm{w}$ innych przedsiębiorstwach. Proponowano im stanowiska znacznie poniżej kwalifikacji i za najniższe stawki (Informacja uzyskana 22 IV 2008 r. od zwolnionego z pracy Wiesława Zdanowicza).

77 AIPN Bi, sygn. 012/397, Meldunek z 20 VII 1976, k. 4-5.

78 J. J. Lipski, op. cit., s. 137.

79 Innym "łącznikiem” Kuronia z Warszawą był Stanisław Krajewski, adiunkt w Zakładzie Matematyki Filii UW (Mail S. Krajewskiego do autora z 23 V 2008), a także Gaja Kuroń (Notacja Zofii Lewickiej-Pezowicz z 11 V 2017, real. T. Piotrowski, w zbiorach Oddziałowego Biura Badań Historycznych IPN w Białymstoku).

80 Relacja B. Pezowicza z 16 V 2008 (w zbiorach autora); Relacja S. Pogorzelskiego z 8 V 2008 (w zbiorach autora).

81 List Zofii Lewickiej-Pezowicz do autora z 15 II 2008. 
ocen dotyczących KOR oraz zachowania Lewickiej-Pezowicz i jej powiązań ze środowiskiem twórczym, ten stale meldował, że tematy dotyczące KOR są poruszane rzadko i bez głębszego zainteresowania rozmówców ${ }^{82}$. Informacje na temat KOR miał - według SB - rozpowszechniać w grudniu $1976 \mathrm{r}$. Michał Dachtera, muzyk Filharmonii Białostockiej. Według relacji TW „Zaremby" miał on opowiadać, że Komitet reprezentują

ludzie cieszący się autorytetem w kraju i za granicą. Komitet ten rozwija rzekomo dużą działalność i działa półlegalnie. Wydaje biuletyny, stosuje petycje do władz krajowych oraz rządów i partii komunistycznych innych państw ${ }^{83}$.

Więcej informacji o Komitecie przywiózł z Warszawy popularny wówczas baryton Remigiusz Kossakowski. Według TW "Zaremby”, Kossakowski miał opowiadać o głównych celach działalności KOR: „obronie praw człowieka w myśl karty ONZ i ustaleń w Helsinkach, [...] rozliczeniu z niechlubną przeszłością", reformie prawodawstwa i zmianach w systemie rządzenia, a także o istnieniu podobnych komitetów w ZSRS i Czechosłowacji ${ }^{84}$. Dobrze poinformowany w kwestii działalności KOR był także Jerzy Zegarski, inżynier z Przedsiębiorstwa Doświadczalnego Opakowań „Pakpol”, a prywatnie szwagier Jana Lityńskiego ${ }^{85}$. Kolporterem bezdebitowej literatury KOR był też mieszkający od połowy lat siedemdziesiątych w Białymstoku archeolog Krzysztof Burek, brat związanego z Komitetem krytyka literackiego Tomasza Burka ${ }^{86}$. Niewielkie ilości „Robotnika” regularnie przywoził z Warszawy Krzysztof Lachowski, student Politechniki Warszawskiej, a zarazem drukarz KOR i przekazywał je swojemu bratu Lechowi, robotnikowi

82 W swoim meldunku z 24 listopada 1976 r. TW „Waldemar" poinformował o swojej rozmowie z poetą Wiesławem Kazaneckim, od którego miał się dowiedzieć, że „na terenie kraju w szeregu zakładach działają nielegalne komitety fabryczne, które spełniają rolę przeciwwagi związków zawodowych". Informację tę prawdopodobnie przywiózł z Warszawy Edward Redliński (AIPN Bi, sygn. 009/269/2, Informacja operacyjna ze spotkania z TW „Waldemar", 24 XI 1976, k. 72-73). AIPN Bi, sygn. 009/205/2, Informacja TW „Zaremba” nr 78/379/76, 2 XII 1976, k. 203-203v. Ibidem, Informacja TW „Zaremba” nr 79/379/77, 18 III 1977, k. 205-205v.

Zegarski w 1977 r. był rozpracowywany przez SB w ramach kwestionariusza ewidencyjnego "Chemik" w związku z kilkakrotnym udziałem w spotkaniach Komitetu w mieszkaniu Lityńskiego i „,wspierania osób prowadzących wrogą działalność polityczną i represjonowanych za tę działalność oraz ich rodzin" (AIPN Bi, sygn. 0037/186/2, Plan podstawowych działań operacyjnych Wydziału IIIA KW MO w Białymstoku na 1981 r. oraz ocena stanu bezpieczeństwa za 1980 r., styczeń 1981, k. 13. Por.: Wypis ewidencyjny OBUiAD w Białymstoku dot. J. Zegarskiego z 18 IV 2008).

86 Informacja uzyskana przez autora od Krzysztofa Burka w 2008 r. 
z „Biazetu” 87. W październiku 1977 r. oficer prowadzący TW „Waldemara” zlecił mu sprawdzenie, czy w jego otoczeniu nie jest kolportowany "Robotnik", „Opinia”, „Biuletyn Informacyjny”, „Na wprost”, ,Aneks” bądź paryska „Kultura” 88. Skala kolportażu „bibuły” była jednak na Białostocczyźnie niewielka, a prowadzone przez SB sprawy operacyjne dotyczyły osób kontaktujących się z KOR-em lub ROPCiO i przywożących głównie ze stolicy pojedyncze egzemplarze nielegalnych gazetek. Esbecy za wszelką cenę starali się jakichś kolporterów ustalić, posuwając się nawet do wręczenia w kwietniu 1978 r. TW „Zarembie”, działającemu w kręgu muzyków Filharmonii, trzech egzemplarzy "Robotnika”, żeby wiedział, czego ma szukać ${ }^{89}$.

Najlepsze warunki do powstania grup opozycyjnych istniały na białostockiej Filii UW, w interesującym, choć nieco wyalienowanym z lokalnej społeczności środowisku wykładowców "zesłanych” tu na początku lat siedemdziesiątych. Jak wspominał Stefan Meller:

[...] filia w Białymstoku stała się miejscem absolutnie wyjątkowym na mapie ówczesnych polskich uczelni, ponieważ $\mathrm{w}$ znacznej mierze pracowali tam ludzie po przejściach, do niedawna objęci zakazami zatrudnienia, i tacy, którzy $\mathrm{z}$ różnych powodów podpadli władzy ludowej. [...] w imię regionalnych ambicji, partyjne władze Białegostoku stworzyły w filii UW, zwłaszcza w Instytucie Historii, potężny ośrodek intelektualnej opozycji ${ }^{90}$.

W grupie tej znajdowali się zarówno ludzie związani z wydarzeniami marca 1968 r., jak i zaangażowani później w działalność „korowską”, bądź po prostu pozostający w opozycji intelektualnej do systemu; historycy: Daniel Grinberg, Elżbieta Kaczyńska, Jan Kofman, Adam Manikowski, Stefan Meller; prawnicy: Andrzej Stelmachowski, Jarosław Kaczyński, filozof Stanisław Krajewski i inni ${ }^{91}$. Zamysł władz, mający na celu izolację tych osób od warszawskiego otoczenia i „osadzenie” na prowincji okazał się dość skuteczny. Wskutek tych działań środowisko to, samo w sobie bardzo silne, nie stało się ośrodkiem

87 Informacja uzyskana od Krzysztofa i Lecha Lachowskich. Zob. też: K. Lachowski, Figurant. Dokumenty Stużby Bezpieczeństwa. Sprawa operacyjnego rozpracowania 25723 - kryptonim "Ptak", teczka z lat 1979-1982, Białystok 2005, s. 7.

88 AIPN Bi, sygn. 009/269/2, Informacja operacyjna ze spotkania z TW „Waldemar”, 17 X 1977, k. 88.

89 AIPN Bi, sygn. 009/205/2, Informacja TW „Zaremba” nr 86/379/78, 29 IV 1978, k. 217v.

90 Świat według Mellera. Życie i historia: ku wolności. Ze Stefanem Mellerem rozmawia Michał Komar, t. 1, Warszawa 2008, s. 143.

91 Do pracy na białostockich uczelniach dojeżdżało w 1975 r. z Warszawy 78 osób (AIPN Bi, sygn. 045/2162/13, Program działań operacyjnych Wydziału III KW MO w Białymstoku do 1980 r., 23 IX 1975, k. 2). 
integrującym lokalne elity. Niewątpliwie odegrało pewną rolę w kolportażu druków i literatury podziemnej wśród miejscowej kadry naukowej, natomiast w sposób trudny do przecenienia oddziaływało swoim potencjałem intelektualnym na studentów ${ }^{92}$.

$\mathrm{W}$ związku z rozwijającym się w kilku największych miastach w kraju ruchem studenckich komitetów solidarności (SKS), zgodnie z zaleceniem Wydziału III Departamentu III MSW, również w Białymstoku rozpoczęto prowadzenie sprawy obiektowej krypt. „Powój”, której celem było rozpoznanie środowiska akademickiego ( $w$ tym DA i poszczególnych księży pracujących ze studentami) pod tym kątem i przeciwdziałanie takim próbom ${ }^{93}$. Planowano wyrywkową kontrolę korespondencji kierowanej do uczelni i organizacji studenckich, a także podsłuchiwanie rozmów telefonicznych. Od władz uczelni domagano się wzmożenia kontroli osób przebywających w akademikach i na terenie szkól, a także treści informacji wywieszanych na tablicach ogłoszeniowych ${ }^{94}$. W końcu sierpnia 1979 r. białostocka SB w ramach sprawy „Powój” opracowała „Plan organizacyjnego zabezpieczenia środowiska młodzieży szkolnej i akademickiej przed próbami ROPCiO [Ruchu Obrony Praw Człowieka i Obywatela] powołania na naszym terenie nielegalnej organizacji pn. »Ruch Młodej Polski«". Wśród osób podejrzewanych o potencjalne kontakty z RMP wymieniano studentów AMB, u których znaleziono pojedyncze egzemplarze pism korowskich: Krzysztofa Klonowskiego, Janusza Korfela, Dariusza Żendziana; także Wojciecha Krutula z PB oraz ks. Jana Sochonia i Jana Leończuka, pracownika naukowego FUW, kontrolowanych w ramach sprawy operacyjnego sprawdzenia krypt. „Emisariusz” w związku z - jak to określono - organizowaniem „nieformalnych grup szkoleniowych”. Agenturze polecono prowadzenie akcji dezinformacyjnej, polegającej na przedstawianiu RMP jako organizacji inspirowanej przez „wrogie ośrodki na Zachodzie”, której celem jest „przechwycenie przez znanych graczy politycznych młodzieży do ich politykierskich rozgrywek" ${ }^{\prime 9}$. Prowadzenie sprawy obiek-

92 W 1980 r. istotnie zaważyło to na powstaniu w Białymstoku silnych struktur Niezależnego Zrzeszenia Studentów.

93 Inwigilowano głównie wykładowców dojeżdżających z Warszawy, a także białostoczanina, Macieja Juniewicza, asystenta na Wydziale administracyjno-ekonomicznym Filii UW, w latach 1976-1977 związanego z KOR (AIPN Bi, sygn. 011/61, Plan przedsięwzięć operacyjnych..., k. 19). Rzecznikiem warszawskiego SKS był wspomniany Krzysztof Lachowski (Kryptonim "Wasale”. Stużba Bezpieczeństwa wobec Studenckich Komitetów Solidarności 1977-1980, wyb., wstęp i opr. Ł. Kamiński, G. Waligóra, Warszawa 2007, s. 430. Por. też: J. J. Lipski, op. cit., s. 479, 510). 
towej „Powój” zakończono 11 listopada 1980 r. z powodu niestwierdzenia „Wrogiej działalności" 96.

Brak regionalnych struktur opozycyjnych świadczył o panującej w lokalnych społecznościach apatii. Nawet środowiska tylko potencjalnie niebezpieczne dla władz były wręcz nachalnie inwigilowane, co powodowało ich izolację. W tej sytuacji tylko jednostki odważne, często zdesperowane czy skonfliktowane $\mathrm{z}$ lokalnymi środowiskami nie bały się wejść $\mathrm{w}$ konflikt $\mathrm{z}$ władzą $\mathrm{i}$ to one prezentowały postawy sprzeciwu, które stawały się powszechne w czasie "karnawału Solidarności”. Jedną z takich osób był wspomniany już Henryk Szczerba, który 1 stycznia 1977 r. wysłał do Rady Państwa wniosek w sprawie powołania przez sejm specjalnej komisji ds. zbadania przyczyn wydarzeń czerwcowych, a w kolejnych tygodniach listy do ambasady ZSRS, KOR-u, prymasa, sejmu i Rady Państwa, w których stawiał wniosek m.in. „niezwłocznego aresztowania ob. Edwarda Gierka, rozwiązania SB, uzbrojenia ugrupowań opozycji [!]" itp. 2 maja Wydział Śledczy KW MO w Białymstoku wszczął wobec niego dochodzenie, zaś Wydział III - rozpracowanie operacyjne krypt. „Pisarz”. Działalność Szczerby SB zamierzała sprowadzić do „choroby psychicznej poważnie zagrażającej porządkowi prawnemu PRL" i umieścić go w zamkniętym oddziale szpitala psychiatrycznego ${ }^{97}$, co Szczerba uznał za działanie bezprawne i poinformował listownie o swojej sytuacji Andrzeja Czumę i Leszka Moczulskiego. Wkrótce pojechał do Warszawy, gdzie spotkał się z działaczami ROPCiO i adwokatem Władysławem Siła-Nowickim, który podjął się reprezentowania go w tej sprawie ${ }^{98}$. Dzięki interwencji mecenasa, próba odizolowania Szczerby została udaremniona. Sprawa ta była ponoć poruszana podczas konferencji prasowych ROP$\mathrm{CiO}^{99}$. Mimo prowadzonego śledztwa, w połowie $1977 \mathrm{r}$. Szczerba rozpoczął publikowanie swoich artykułów na łamach „Opinii". Jeden z nich miał nawet być w całości odczytany na antenie RWE100.

przed próbami ROPCiO powołania na naszym terenie nielegalnej organizacji pn. „Ruch Młodej Polski", 30 VIII 1979, k. 23-25v.

Ibidem, Wniosek o zakończenie (zaniechanie) sprawy obiektowej kryptonim „Powój”, 11 XI 1980, k. 61v.

AIPN Bi, sygn. 012/390, Meldunek zastępcy naczelnika Wydziału III KW MO w Białymstoku, 19 VII 1977, k. 12v.

98 Ibidem, Meldunek naczelnika Wydziału III KW MO w Białymstoku, 8 VI 1977, k. 9v.

99 Ibidem, Meldunek naczelnika Wydziału III KW MO w Białymstoku, 25 VII 1977, k. 11v.

100 Być może chodzi o tekst Rolnik pod batem poganiaczy z urzędu, „Opinia” 1977, nr 6, s. 16-17, w którym opisywał sytuację w gminie Sidra, gdzie Naczelnik, grożąc wszczęciem procedury wywłaszczenia gospodarstw, nakazywał rolnikom wykupywanie zapasów nawozów sztucznych. 
W 1979 r. Wydział III białostockiej SB rozpoczął intensywne rozpracowanie weterana ruchu ludowego Jakuba Antoniuka ${ }^{101}$, który 15 kwietnia w Warszawie podpisał deklarację powołującą do życia niezależny Ośrodek Myśli Ludowej. Wykorzystując jego wyobcowanie w środowisku sąsiedzkim, jak również złe stosunki rodzinne oraz skłonność do rozmów z przypadkowo poznanymi ludźmi, SB aranżowała spotkania Antoniuka z zakonspirowanym funkcjonariuszem, który uzyskiwał $\mathrm{w}$ ten sposób informacje na temat działalności Ośrodka. Funkcjonariusze liczyli też, że uda się im dzięki temu zneutralizować nielegalną działalność Antoniuka 102. „Figurant” wkrótce zorientował się, że ma do czynienia z SB i podjął z oficerami, którzy niebawem zresztą przestali ukrywać, kim są, grę podobną do tej, jaką prowadził w latach 50. Przekazywał im wybrane informacje o przebiegu warszawskich spotkań OML będąc pewnym, że nie będą w stanie ich zweryfikować103. W marcu opracował na zamówienie Departamentu IIIA MSW charakterystykę grup opozycyjnych działających w kraju i przedstawił ją pracownikowi Departamentu mjr. Wacławowi Ułanowskiemu. Antoniuk miał także zadeklarować dalsze kontakty z nim. Funkcjonariusze doskonale zdawali sobie sprawę, że Antoniuk mówi im tylko to, co chce i podejmuje równocześnie działania o charakterze antysystemowym. Na przykład w grudniu 1979 r. zredagował petycję rolników z gminy Dobrzyniewo do I sekre-

101 Antoniuk był w czasie wojny komendantem powiatu Białystok BCh, a po wojnie wicewojewodą białostockim z ramienia SL. Decydujące dla jego późniejszego życiorysu było aresztowanie przez UB w grudniu 1944 r. pod zarzutem współpracy z AK i skazanie 26 II 1945 r. na karę śmierci, a następnie - w wyniku interwencji NK SL - złagodzenie tej kary przez Bolesława Bieruta do 10 lat więzienia, prawdopodobnie za cenę poparcia przez Antoniuka „bloku demokratycznego" przed zbliżającymi się wyborami. Zwolniony z więzienia we Wronkach 3 I 1947 r. (J. J. Milewski, Jakub Antoniuk (1911-1988), [w:] Konspiracja i opór społeczny w Polsce 1944-1956. Słownik biograficzny. T. I, Kraków-Warszawa-Wrocław 2002, s. 12-14). Według akt UB przechowywanych w IPN, Antoniuk został 20 VI 1949 r. zwerbowany do tajnej współpracy przez WUBP w Białymstoku. Nadano mu pseudonimy „Adamski” i „Borkowski”. W 1956 r. funkcjonariusze UB stwierdzili, że doniesienia agenturalne Antoniuka były zmyślone. Został „zdemaskowany jako dezinformator i dwulicowiec i na tej podstawie wyeliminowany" z dalszej współpracy. W tym czasie domagał się na forum WK ZSL w Białymstoku zerwania współpracy z PZPR oraz zmiany kierownictwa w ZSL i PZPR. W 1961 r. po raz drugi został wykluczony z ZSL za „działalność prawicową" (AIPN, sygn. 01236/20). W 1977 r. SB zaczęła go rozpracowywać w ramach kwestionariusza ewidencyjnego krypt. "Zagorzały” w związku z prowadzeniem przez niego działalności skierowanej przeciwko „linii politycznej partii”, zakończony z powodu „zaniechania prowadzenia wrogiej działalności". Materiały tej sprawy zostały zniszczone. (Wypis kartoteczny OBUiAD w Białymstoku dot. J. Antoniuka, 10 I 2008).

102 AIPN Bi, sygn. 012/302, Meldunek operacyjny, 6 VI 1979, k. 7.

103 Ibidem, Meldunek operacyjny, 13 II 1980, k. 48-48v. 
tarza KW PZPR w Białymstoku w sprawie korupcji w miejscowym GS-ie i nieprawidłowościach w Urzędzie Gminy. Sam poinformował o tym w rozmowie z SB, grożąc powołaniem Komitetu Samoobrony Chłopskiej w wypadku braku interwencji ${ }^{104}$. Z kolei $\mathrm{w}$ marcu, mimo usilnego nakłaniania go przez funkcjonariuszy, nie wziął udziału w wyborach do sejmu, uzasadniając to perspektywą utraty autorytetu w OML i możliwości dalszego pomagania SB ${ }^{105}$. W końcu maja $1980 \mathrm{r}$. Antoniuk podpisał petycję w obronie Jana Kozłowskiego, represjonowanego działacza chłopskiego z okolic Stalowej Woli ${ }^{106}$. Jednak przed funkcjonariuszami tłumaczył się, że podpisu nie złożył, a jedynie zadeklarował taką gotowość, będąc przekonanym, że petycja jest już wysłana do RWE ${ }^{107}$. Regularnie też zdobywał literaturę bezdebitową. Każdy egzemplarz stemplował własną pieczątką zapewniając potem, że „bibuły” nie kolportuje, lecz kolekcjonuje. SB przejmowała jego korespondencję i werbowała wokół niego agenturę. Utrzymywanie kontaktu operacyjnego z Antoniukiem i zlecanie mu kolejnych ekspertyz miało na celu jak przyznawali sami funkcjonariusze - nie tyle uzyskanie informacji, ile raczej zajęcie go, by nie miał czasu na „prowadzenie wrogiej działalności” 108 oraz,$[\ldots .$.$] oddziaływanie na niego w kierunku osłabienia i neutralizowania$ jego wrogiego stosunku do władzy ludowej"109. W maju 1980 r. Wydział III Departamentu IIIA MSW zlecił Antoniukowi wykonanie nieustalonego zadania dotyczącego OML, nie wiadomo jednak, czy uczynił cokolwiek by je wykonać $^{110}$. Po sierpniu 1980 r. Antoniuk zaangażował się w tworzenie regionalnych struktur związków rolniczych ${ }^{111}$.

\footnotetext{
104 Ibidem, Meldunek operacyjny, 7 I 1980, k. 42.

105 Ibidem, Meldunek operacyjny, 5 IV 1980, 56v.

106 J. J. Lipski, op. cit., s. 486.

107 AIPN Bi, sygn. 012/302, Meldunek operacyjny, 7 VI 1980, k. 60v.

108 Ibidem, Meldunek operacyjny, 25 III 1980, k. 53v-55.

109 Ibidem, Meldunek operacyjny, 5 IV 1980, 56v.

110 Ibidem, Meldunek operacyjny, 7 VI 1980, k. 60v, Meldunek operacyjny, 23 IX 1980, k. 68v.

111 Więcej na temat opozycyjnej działalności Antoniuka zob.: T. Danilecki, Przywódcy rolniczej "Solidarności" na Białostocczyźnie - drogi chłopskich (non)konformistów do działalności opozycyjnej, (referat wygłoszony podczas ogólnopolskiej konferencji naukowej pt. Ruch ludowy i polska wieś wobec niepodległości. Supraśl-Nidzica, 19-21 IX 2018 r., w druku); J. Beszta-Borowski, Pót wieku zarazy. Moje zapiski faktów i refleksji, Komorów [b.r.w.]; M. Kietliński, Niezależny Samorzadny Związek Zawodowy Rolników Indywidualnych "Solidarność" w województwie białostockim w latach 1980-1981, [w:] Mój Kościót w historię wpisany. Księga pamiatkowa dedykowana Księdzu Profesorowi Tadeuszowi Krahelowi, red. T. Kasabuła, A. Szot, Białystok 2007. W latach osiemdziesiątych Antoniuk występuje w aktach SB jako TW ps. „Radziszewski” (Wypis ewidencyjny BUiAD w Warszawie dot. J. Antoniuka, 8 V 2008). Zmarł 10 lipca 1988 r.
} 
Innego rodzaju działalność rozpoczął na początku 1980 r. Kazimierz Bakun, rolnik ze wsi Starowlany (gm. Kuźnica Białostocka). Mając kłopoty związane z działalnością lokalnych urzędników i banków, opisał swoją sytuację w skardze do Komitetu Praw Człowieka w Genewie i zwrócił się do Przewodniczącego Rady Państwa o pozbawienie go obywatelstwa polskiego. Skontaktował się także z Jackiem Kuroniem i Wiesławem Kęcikiem, który obiecał mu pomoc ${ }^{112}$. Wkrótce rozpoczął kolportaż „Placówki”, „Robotnika”, „Bratniaka", "Zeszytów TKN" i innych wydawnictw bezdebitowych wszędzie, gdzie tylko zdołał: w pociągach, w miejscu pracy, wśród znajomych, na jarmarkach oraz w zakładach pracy Sokółki i Białegostoku; rozdawał je również kierowcom PKS i kolejarzom w celu kolportażu po całym regionie. Przedstawiał się oficjalnie jako współpracownik KOR. Ponieważ mieszkał w ścisłej strefie przygranicznej, jego zachowanie zostało natychmiast zauważone przez osobowe źródła informacji Wydziału II WOP, który poinformował o jego aktywności SB. 9 kwietnia 1980 r. Wydział IIIA KW MO w Białymstoku rozpoczął prowadzenie sprawy operacyjnego sprawdzenia krypt. "Gazeta”, w celu zablokowania działalności Bakuna. Mimo gróźb stosowanych przez SB na zmianę z obietnicami rozwiązania jego problemów, Bakun nie przerwał kolportażu i publicznie krytykował porządki panujące na wsi. Na prośbę Kęcika podjął się znalezienia kolportera „Robotnika” na terenie fabryk Białegostoku. W tej sprawie zwrócił się do znajomego, byłego pracownika Fabryki Maszyn Rolniczych w Czarnej Białostockiej, który okazał się zarazem kontaktem operacyjnym SB o pseudonimie "Czesław"113. Na początku maja Bakun przekazał mu kilkaset egzemplarzy różnych pism do rozpowszechnienia. Za pośrednictwem "Czesława” SB podstawiła Bakunowi pracownika „Uchwytów”, TW ps. „Leszek”, któremu polecono przejąć kolportaż „bibuły” kierowanej do Białegostoku ${ }^{114}$. „Leszkowi” udało się do tego stopnia wzbudzić zaufanie Bakuna, że zaczął zabierać go ze sobą do mieszkania Kęcików w Warszawie. Również u doświadczonego działacza KOR osoba „Leszka” nie wzbudziła niepokoju. TW informował następnie funkcjonariuszy SB o przebiegu tych spotkań, a także przekazywał im całość otrzymywanej bibuły. W celu uwiarygodnienia swojego agenta, SB zorganizowała 27 czerwca w "Uchwytach" fikcyjny kolportaż - dwa egzemplarze „bibuły” przekazano zastępcy dyrektora ds. produkcji, który je pokazał na zebraniu mistrzów i kierowników wydziałów informując, że są to pisma kolportowane nielegalnie w zakładzie

\footnotetext{
112 AIPN Bi, sygn. 0037/186/2, Plan podstawowych działań operacyjnych..., k. 12v.

113 AIPN Bi, sygn. 012/320, Meldunek operacyjny, 10 V 1980, k. 36-38v.

114 Ibidem, Meldunek operacyjny, 14 V 1980, k. 42v.
} 
i polecając, by zwracano uwagę na podobne przypadki ${ }^{115}$. Funkcjonariusze liczyli, że ta informacja dotrze „okrężną drogą" do Bakuna. Inną kombinację operacyjną zastosowano w celu uwiarygodnienia KO „Czesława” w oczach Bakuna i przejęcia jednej z dostaw bibuły. 6 czerwca "Czesław” został fikcyjnie zatrzymany na dworcu PKP w Białymstoku podczas przejmowania od Bakuna przesyłki z prasą ${ }^{116}$, a 21 czerwca dokonano u niego fikcyjnego przeszukania ${ }^{117}$.

Esbecy podejmowali równocześnie działania represyjne wobec Bakuna. Polecili milicjantom z Sokółki kierowanie przeciwko niemu wniosków do kolegium ds. wykroczeń pod byle pretekstem. Nakazali też kierownictwu stacji PKP w Sokółce, gdzie pracował, notowanie wszelkich jego potknięć, wymierzanie kar finansowych i doprowadzenie do zwolnienia z pracy ${ }^{118}$. W efekcie tych działań 25 lipca kolegium w Kuźnicy Białostockiej ukarało Bakuna grzywną w wysokości 5 tys. zł za rzekome wywołanie awantury w sklepie. Przewidując, że niepokorny rolnik odwoła się od tego orzeczenia do kolegium w Białymstoku, funkcjonariusze SB nawiązali kontakt z jego przewodniczącym, któremu „przedstawili sylwetkę figuranta” ${ }^{119}$. Tylko w 1980 r. Bakun stawał pięciokrotnie przed kolegium, które wymierzało mu kary grzywny i aresztu. 27 sierpnia Sąd Rejonowy w Sokółce skazał go na karę pół roku ograniczenia wolności. W wyniku ciągłych szykan, Bakun wkrótce zwolnił się z pracy na kolei i rozpoczął organizowanie $\mathrm{w}$ terenie struktur rolniczych związków zawodowych ${ }^{120}$.

$\mathrm{W}$ działalność opozycyjną $\mathrm{w}$ regionie białostockim angażowali się w latach siedemdziesiątych ludzie, którzy popadali w konflikt z systemem z różnych, nie tylko politycznych przyczyn. Sprzeciw wobec otaczającej rzeczywistości, niezgoda na krzywdę własną lub innych, skłaniała ich do aktywnego działania - wchodzenia w ostry konflikt z władzą (która konsekwentnie stosowała wobec buntujących się "miękkie”, choć nieraz dotkliwe represje), bądź szukania z nią jakiegoś kompromisu (co z kolei narażało ich na uzależnienie i przekroczenie cienkiej linii oddzielającej opór od kolaboracji). Jedną z takich przyczyn były także wszelkie próby organizowania życia religijnego, wykra-

\footnotetext{
115 Ibidem, Meldunek operacyjny, 2 VII 1980, k. 62v.

116 Ibidem, Meldunek operacyjny, 11 VI 1980, k. 54v.

117 Ibidem, Meldunek operacyjny, 25 VI 1980, k. 61v.

118 Ibidem, Meldunek operacyjny, 10 V 1980, k. 38v.

119 Ibidem, Meldunek operacyjny, 25 VII 1980, k. 67v.

120 O działalności opozycyjnej Bakuna po sierpniu 1980 r. zob.: T. Danilecki, Kazimierz Bakun [biogram], [w:] Encyklopedia Solidarności. Opozycja w PRL 1976-1989, t. 2, s. 24; idem, Przywódcy rolniczej „Solidarności”.... Bakun zmarł 8 XII 1998 r. w USA.
} 
czające poza rutynowe uczestnictwo w nabożeństwach. Władze uznawały je za działalność antysystemową. Protesty robotnicze, do których doszło na Białostocczyźnie w roku 1970 i 1976 były wprawdzie motywowane ekonomicznie, jednak represje zastosowane przez władze wobec ich uczestników nadały im wymiar polityczny.

Postawy sprzeciwu były $w$ latach siedemdziesiątych dalekie od powszechnej akceptacji. Otoczenie - nauczone bierności i posłuszeństwa, bądź z obawy przed represjami (łatwymi do zastosowania zwłaszcza w zamkniętych, prowincjonalnych środowiskach) - przeważnie dystansowało się od manifestujących je osób. Zrozumienie i oparcie znajdowały one jedynie w bardzo wąskich wówczas kręgach ludzi myślących podobnie, bądź wśród najbliższych.

W warunkach kryzysu systemu, który nastąpił w latach osiemdziesiątych, "dysydenci" z poprzedniej dekady zaangażowali się w ruch solidarnościowy, jednak zazwyczaj nie odegrali w nim ról kierowniczych.

\section{Bibliografia}

\section{Źródła archiwalne}

Archiwum Instytutu Pamięci Narodowej w Warszawie

Sygn.: 02240/24, t. 1-2.

Archiwum Państwowe w Białymstoku

Komitet Miejski Polskiej Zjednoczonej Partii Robotniczej w Białymstoku Sygn.: 113.

Komitet Wojewódzki Polskiej Zjednoczonej Partii Robotniczej w Białymstoku Sygn.: 807, 808.

Komitet Zakładowy Polskiej Zjednoczonej Partii Robotniczej Białostockich Zakładów Przemysłu Bawełnianego Fasty

Sygn.: 10.

Oddziałowe Archiwum Instytutu Pamięci Narodowej w Białymstoku Sygn.: 009/205/2, 009/269/2, 0037/186/2, 011/61, 012/302, 012/320, 012/390, 012/397, 012/1438, 015/712/1, 015/775, 015/776, cz. I i II, 045/246, 045/2162/ $13,047 / 1839,01236 / 20$.

\section{Źródła drukowane}

Kryptonim „Wasale”. Stużba Bezpieczeństwa wobec Studenckich Komitetów Solidarności 1977-1980, wyb., wstęp i opr. Ł. Kamiński, G. Waligóra, Warszawa 2007.

Plany pracy Departamentu IV MSW na lata 1972-1979, wyb. i opr. M. Biełaszko et al., Warszawa 2007. 


\section{Materiały niepublikowane}

Danilecki T., Między zaangażowaniem, przystosowaniem i sprzeciwem. Wybory powszechne a postawy mieszkańców województwa białostockiego w latach 1957-1969, (mps. rozprawy doktorskiej obronionej w 2017 r. na Wydziale Historyczno-Socjologicznym Uniwersytetu w Białymstoku, w druku).

Danilecki T., Przywódcy rolniczej „Solidarności” na Białostocczyźnie - drogi chłopskich (non)konformistów do działalności opozycyjnej, (referat wygłoszony podczas ogólnopolskiej konferencji naukowej pt. Ruch ludowy i polska wieś wobec niepodległości. Supraśl-Nidzica, 19-21 IX 2018 r., w druku).

Danilecki T., Zofia Lewicka - od komandoski do streetworkerki, (w druku).

Danilecki T., Zwolski M., Opozycja przedsierpniowa (1975-1980) w województwach białostockim, łomżyńskim i suwalskim (mps w zbiorach autora).

\section{Relacje i wspomnienia}

Beszta-Borowski J., Pół wieku zarazy. Moje zapiski faktów i refleksji, Komorów [b.r.w.].

Bujwicki B., Mój rok 1980, Białystok 2013.

Lachowski K., Figurant. Dokumenty Służby Bezpieczeństwa. Sprawa operacyjnego rozpracowania 25723 - kryptonim "Ptak”, teczka z lat 1979-1982, Białystok 2005.

Notacja Zofii Lewickiej-Pezowicz z 11 V 2017, real. T. Piotrowski, w zbiorach Oddziałowego Biura Badań Historycznych IPN w Białymstoku.

Relacja Bogusława Pezowicza z 16 V 2008 (w zbiorach autora).

Relacja Stanisława Pogorzelskiego z 8 V 2008 (w zbiorach autora).

Relacje zwolnionych tkaczek, opr. tl [Teresa Leszczyńska], „Biuletyn MKZ NSZZ »Solidarność« Regionu Białystok”, nr 30, 24 VI 1981.

Sprawa pięciu mistrzów Tkalni Białej, [opr. MM, ZLP], „Biuletyn Informacyjny MKZ NSZZ »Solidarność« Regionu Białystok” nr 30, 24 VI 1981.

Świat według Mellera. Życie i historia: $k u$ wolności. Ze Stefanem Mellerem rozmawia Michał Komar, t. 1, Warszawa 2008.

\section{Artykuły}

Autuchiewicz J., "Jakiśs” reportaż Edwarda Redlińskiego, „Biuletyn Instytutu Pamięci Narodowej" 2008, nr 8-9, s. 82-85.

Bäcker R., Opozycja a totalitaryzm. Problemy klasyfikacyjne, [w:] Opozycja w systemach demokratycznych i niedemokratycznych, red. K. Łabędź, M. Mikołajczyk, Kraków 2001, s. 57-64.

Boćkowski D., Marzec '68 w Białymstoku w świetle materiałów operacyjnych KW MO, „Dzieje Najnowsze” 2008, nr 1, s. 195-202.

Damulewicz P., Duszpasterz z autorytetem, „Goniec Knyszyński” 2004, nr 3, s. 14.

Danilecki T., Dwaj literaci, „Biuletyn Instytutu Pamięci Narodowej” 2005, nr 12, s. 28-39. 
Danilecki T., Kazimierz Bakun [biogram], [w:] Encyklopedia Solidarności. Opozycja w PRL $1976-1989$, t. 2, s. 24.

Danilecki T., Mieszkańcy Białostocczyzny wobec stanu wojennego, „Rocznik Białostocki” 2018, t. XXI, s. 305-313.

Danilecki T., NSZZ „Solidarność" i opozycja demokratyczna w województwie białostockim u schyłku lat osiemdziesiatych XX w., [w:] Między systemami. Społeczeństwo Polski pótnocno-wschodniej wobec przemian ustrojowych 1989 roku, red. M. Markiewicz, A. Pyżewska, Białystok 2014, s. 52-68.

Danilecki T., Stan badań nad powojennymi dziejami podziemia niepodległościowego w województwie białostockim, [w:] Podziemie niepodległościowe w województwie białostockim w latach 1944-1956, red. T. Danilecki, Warszawa 2004, s. 13-27.

Danilecki T., Zwolski M., Podlasie i Suwalszczyzna, [w:] Stan wojenny w Polsce 1981-1983, red. Antoni Dudek, Warszawa 2003, s. 413-475.

Gierasimiuk U., Marzec 1968 r. w województwie białostockim w świetle materiałów aparatu bezpieczeństwa, [w:] „Mała stabilizacja” w województwie białostockim 1956-1970, red. M. Markiewicz, Białystok 2012, s. 157-169.

Kamiński Ł., Waligóra G., Małe ośrodki ruchu związowego i ich rola w latach 1980-1990, [w:] Tam też była "Solidarność". Małe ośrodki ruchu zwiqzzkowego i ich rola w latach 1980-1990, red. A. Pyżewska, M. Zwolski, Białystok 2012, s. 14-18.

Kietliński M., Białystok na zakrętach PRL 1956-1976, „Gryfita” 2000, nr 22, s. 15-19.

Kietliński M., Niezależny Samorządny Zwiazek Zawodowy Rolników Indywidualnych „Solidarność" w województwie białostockim w latach 1980-1981, [w:] Mój Kościót w historię wpisany. Ksiegga pamiątkowa dedykowana Księdzu Profesorowi Tadeuszowi Krahelowi, red. T. Kasabuła, A. Szot, Białystok 2007.

Kietliński M., Postawy władzy i opozycji w województwie białostockim u schytku lat osiemdziesiatych XX w., [w:] Między systemami. Społeczeństwo Polski pótnocno-wschodniej wobec przemian ustrojowych 1989 roku, red. M. Markiewicz, A. Pyżewska, Białystok 2014, s. 69-89.

Krzemiński I., Antysemityzm, socjalizm i "nowa świadomość". Długofalowe konsekwencje Marca 68 [w:] Marzec 1968. Trzydzieści lat później. Materiały konferencji zorganizowanej pod patronatem Prezydenta m. stoł. Warszawy przez Instytut Historyczny UW, Instytut Studiów Politycznych PAN oraz Żydowski Instytut Historyczny przy wspótpracy Wydawnictwa Naukowego PWN SA na Uniwersytecie Warszawskim 6 i 7 marca 1998 r. Tom I. Referaty, red. M. Kula et al., Warszawa 1998, s. 261-283.

Malczyk A., Markiewicz J.,Wstęp, [w:] Województwo białostockie w ocenie SB 1980-1985, Białystok 2011, s. 15-42.

Milewski J. J., Jakub Antoniuk (1911-1988), [w:] Konspiracja i opór społeczny w Polsce 1944-1956. Stownik biograficzny. T. I, Kraków-Warszawa-Wrocław 2002, s. 12-14.

Pogorzelski K., Sychowicz K., „TW Kastuś” i Służba Bezpieczeństwa a środowisko białoruskie na Białostocczyźnie, „Aparat represji w Polsce Ludowej 1944-1989” 2008, nr 1, s. 227-246.

Rolnik pod batem poganiaczy z urzędu, "Opinia” 1977, nr 6, s. 16-17. 
Sadowska J., Białystok za Gomułki i za Gierka (1956-1980), [w:] Historia Białegostoku, red. A. Cz. Dobroński, Białystok 2012, s. 505-555.

Sadowska J., Epilog historii białostockich Żydów - okres powojenny [w:] Kres świata białostockich Żydów, red. D. Boćkowski et al., Białystok [b.r.w.], s. 86-90.

Sadowska J., W poszukiwaniu normalności - młodzież Białostocczyzny czasów "małej stabilizacji” (1956-1970), [w:] „Mała stabilizacja” w województwie białostockim 1956-1970, red. M. Markiewicz, Białystok 2012, s. 171-196.

Stefaniak M., Sprawa Jacka Smykała jako przykład działalności aparatu represji wobec uczestników Duszpasterstwa Akademickiego o. Huberta Czumy SJ, [w:] Między Warszawa a regionem. Opozycja przedsierpniowa na Pomorzu Zachodnim, red. K. Kowalczyk et al., Szczecin 2008, s. 149-163.

Sychowicz K., NSZZ „Solidarność” Region Białystok [w:] NSZZ Solidarność 1980-1989, t. 5. Polska środkowo-wschodnia, red. Ł. Kamiński, G. Waligóra, Warszawa 2010, s. 11-107.

Walicki A., Twórcy i kultura Białegostoku. Refleksje z badań środowiskowych, [w:] Studia nad procesami rozwoju regionu białostockiego w 40-leciu PRL, red. M. Gnatowski et al., Białystok 1985.

Zwolski M., NSZZ „Solidarność” Region Pojezierze, [w:] NSZZ Solidarność 1980-1989, t. 5. Polska środkowo-wschodnia, red. Ł. Kamiński, G. Waligóra, Warszawa 2010, s. 111-159.

\section{Opracowania}

Białostockie, red. M. Gnatowski, Warszawa 1969.

Friszke A., Opozycja polityczna w PRL 1945-1980, Londyn 1994.

Kietliński M., Stan wojenny na Białostocczyźnie 13 grudnia 1981-22 lipca 1983, Białystok 2001.

Kietliński M., Szkice do dziejów stanu wojennego w województwie białostockim, Białystok 2012.

Lipski J. J., KOR. Komitet Obrony Robotników. Komitet Samoobrony Społecznej, Warszawa 2006.

Markiewicz M., Kolektywizacja wsi w województwie białostockim 1948-1956, Białystok 2010.

Markiewicz M., Odwilż na prowincji. Białostocczyzna 1956-1960, Białystok-Warszawa 2019.

Milewski J. J., Województwo białostockie. Zarys dziejów (1919-1975), Białystok 2011.

Mironowicz E., Polityka narodowościowa PRL, Białystok 2000.

Niezłomni. Nigdy przeciw Bogu, komunistyczna bezpieka wobec biskupów polskich, red. J. Marecki, F. Musiał, Warszawa-Kraków 2007.

Podziemie niepodległościowe w województwie białostockim w latach 1944-1956, red. T. Danilecki, Warszawa 2004.

Polska w liczbach, Warszawa 1985.

Sadowski A., Procesy ruralizacji. Ludność wiejska w mieście, Kraków 1994. 
Sasanka P., Czerwiec 1976. Geneza, przebieg, konsekwencje, Warszawa 2017.

Schabieński J., Sychowicz K., Wydarzenia roku 1976 w Polsce pótnocno-wschodniej, Suwałki 2010.

Studenci Warszawy. Studium długofalowych przemian postaw i wartości, red. S. Nowak, Warszawa 1991.

Świda-Ziemba H., Człowiek wewnętrznie zniewolony. Problemy psychosocjologiczne minionej formacji, Warszawa 1998.

\section{Publikacje internetowe}

Danilecki T., Zofia Lewicka-Pezowicz [biogram], www.encysol.pl, [dostęp: 10 XII 2018]. Konwicka T. et al., Obraz świata w roku 2000. Raport wstępny na podstawie badania z roku 1967, Warszawa 1969, [www.tnsglobal.pl, dostęp: 5 XI 2010].

\section{Between March and August. \\ The examples of dissident attitudes among the inhabitants of the Białystok region at the end of the 1960s and in the 1970s}

\section{Summary}

Based on the internal materials of the state apparatus (including the Security Service), but also those of the Roman Catholic Church and accounts of the time witnesses and participants, the article shows the examples of resistance among the inhabitants of Białystok region against the communist regime in the 1970s, repression used against them as well as the reactions of the conformist surroundings. At that time it was usually the non-conformist individuals who came into ideological conflict with the authority. The foundations of group protests were then solely economic issues. The spread of attitudes of resistance was significantly affected by the experience of student protests from March 1968. The students who, having been dismissed from University, came back to their hometowns, told stories not only about the course of events, but also about the political motives of the protests they had participated in. At the beginning of the 1980s the individuals presenting the attitudes of resistance became actively involved in the "Solidarity" movement and their environment was already better prepared for opposition activity.

Tomasz Danilecki - doktor nauk humanistycznych, historyk, pracownik Działu badań naukowych Muzeum Pamięci Sybiru w Białymstoku. W latach 2001-2018 pracownik Oddziału IPN w Białymstoku. Zainteresowania badawcze: postawy społeczne, aparat bezpieczeństwa w Polsce Ludowej.

e-mail: tdanilecki@poczta.onet.pl 